\title{
Cell Membrane Integrity of Candida Albicans after Different Protocols of Microwave Irradiation
}

\author{
Nara Hellen Campanha ${ }^{1}$, Janaina Habib Jorge ${ }^{2, *}$, Eunice Teresinha Giampaolo ${ }^{2}$, Caio Sergio Botta Martins de \\ Oliveir a $^{3}$, Lí via Nor di Dovigo ${ }^{2}$, Danielle Cardoso G. Maia ${ }^{4}$, Ana Cláudia Pavarina ${ }^{2}$ \\ ${ }^{1}$ Department of Dentistry, State University of Ponta Grossa - UEPG, Paraná, Brazil \\ ${ }^{2}$ Department of Dental Materials and Prosthodontics, Araraquara Dental School, UNESP - Univ. Estadual Paulista, São Paulo, Brazil \\ ${ }^{3}$ General Surgeon Dentist \\ ${ }^{4}$ Program of Biosciences and Biotechnology applied to Pharmacy (Clinical Analyses), Pharmaceutical Sciences School of Araraquara, \\ UNESP - Univ. EstadualPaulista, São Paulo, Brazil \\ *Corresponding author: janainahj@bol.com.br
}

Received March 27, 2013; Revised May 29, 2013; Accepted May 30, 2013

\begin{abstract}
Purpose: To evaluate the ability of low time microwaveexposureto inactivate and damage cell membrane integrity of C. albicans. Materials and Methods: Two $200 \mathrm{ml}$ C. albicans suspensions were obtained. Sterile dentures were placed in a beaker containing Experimental (ES) or Control suspensions (CS). ES was microwaved at $650 \mathrm{~W}$ for 1, 2, 3, 4 or $5 \mathrm{~min}$. Suspensions were optically counted using Methylene blue dye as indicative of membrane-damaged cells; spread on Agar Sabouraud dextrose (ASD) for viability assay; or spectrophotometrically measured at 550nm. Cell-free solutions were submitted to content analyses of protein (Bradford and Pyrogallol red methods); $\mathrm{Ca}^{++}$(Cresolphthalein Complexone method); DNA (spectrophotometer measurements at 260nm) and $\mathrm{K}^{+}$(selective electrode technique). Data were analyzed by Student- $t$ test and linear regression $(\alpha=0.05)$. In addition, flowcytometry analysis of Candida cells in suspensionwas performed using propidium iodide. Results: All ES cells demonstrated cell membrane damage at 3, 4 and 5 min,viable cells were nonexistent at 3, 4 and 5 min ES ASD plates and optical density of ES and CS was not significantly differentfor all exposition times. ES cells released highcontents of protein, $\mathrm{K}^{+}, \mathrm{Ca}^{++}$and DNA after 2 min exposition when compared to that of the CSs. Similar results were observed with flow cytometry analysis with regard to the periodsof microwave exposure. Conclusions: Microwave irradiation inactivated C. albicansafter $3 \mathrm{~min}$ and damaged cell membrane integrity after 2 min exposition.
\end{abstract}

Keywords: microwaves, candida albicans, denture stomatitis, disinfection, denture

\section{Introduction}

Dental prostheses can be source of infection because pathogenic microorganisms are capable to adhere and survive on acrylic resin surfaces, promoting biofilm formation. For this reason, dentures act as a potential cause of cross-infection transmission between patients and dental personnel. Likewise, as a reservoir of pathogens, intaglio surfaces of acrylic resin dentures enhance the infection potential of microorganisms and can favor the riseof oral in fections[1,2].

Oral candidiasis, represented by denture stomatitis in denture wearers, is one of the most common manifestations associated with the use of removable dentures [3]. This condition is mainly caused by microorganisms of the Candida genus and affects the palate of approximately $65 \%$ of denture wearers. Candida albicans represents the predominant species, but the socalled non-albicans Candida species are also recognized as important agents of the infection [2]. Management of denture stomatitis is typically drug based but relapse and recurrence frequently require repeated courses of antifungal therapy [4]. Considering that microbial colonization on dental prostheses favor the appearance of denture stomatitis, cleansing and disinfection of dentures is fundamental to prevent and treat this disease [5].

Decontamination of dentures after exposure to microwave irradiation has shown important results for treatment of denture stomatitis [5] and to prevent crosscontamination. While the inhibitory effect of microwaves on microorganis ms is under research, how microwave brings about this effect is still a matter of debate among many researchers [6-12]. It is generally thought that the destruction of microorganisms is mainly due to a thermal effect $[13,14,15,16]$. However, investigations have attempted to ascertain if such irradiation has a non-thermal effect on microorganis ms $[17,18]$. Rosaspina et al. [19] observed changes in microwaved microorganisms, which were not identified after thermal heat of the cells in water bath. Similarly, injury of cells of Staphylococcus aureus exposed to micro wave irradiation at sublethal temperature has shown to be greater than after conventional heating [18]. Exposition of Bacillus subtilis and Escherichia coli suspensions to microwave irradiation caused reduction on viable cell counts and increased leaching of DNA and protein, suggesting cell membrane cleavage [12]. It has 
been observed that microwave irradiation promoted structural alterations in the cell wall of $C$. albicans adhered to surgical scalpel.

In terms of treating denture stomatitis, $6 \mathrm{~min}$ of micro wave irradiation regimen $(650 \mathrm{~W}$, three times a week for 30 days) was originally recommended to disinfect dental prostheses [20]. Using this protocol, Campanha et al. [21] demonstrated that C. albicans was inactivated after microwave irradiation and changes in cell membrane permeability of $C$. albicans may be involved in cell inactivation. The authors also found that microwave irradiation promoted release of some electrolytes and nucleic acids from Candida cells, and yeasts lost their ellipsoidal morphology [21].

On the other hand, the disinfection protocol of disinfecting dentures with 6 min of microwave irradiation at $650 \mathrm{~W}$ may promote adverse effects on physical and mechanical properties of denture materials [22,23]. Consequently, investigations are seeking alternative protocols, such as short exposure times, which could minimize the occurrence of undesirable effects on the material of dental prostheses. Shorter mic rowave exposure times, e.g. 1 to $5 \mathrm{~min}$ of irradiation, have been found to be effective for denture disinfection [24] and microorganisms inactivation including Candida species [1,5]. Recent clinical trials showed that microwaving for $3 \min (650 \mathrm{~W})$ was an effective method to sterilize complete dentures and also to treat denture stomatitis [25]. Since cell injury caused by the microwave irradiation seems to be proportional to increased temperatures and irradiation times [8], the aim of this study was to evaluate the efficacy of microwave protocols regarding the cell membrane integrity of $C$. albicans after short exposure times.

\section{Material and Methods}

\subsection{Sample Fabrication}

Twenty maxillary dentures were fabricated, according to a standardized procedure described in full detail elsewhere [5]. Briefly, a high-viscosity silicone material was used to obtainanimpression of a standard denture. Waxed denture replicas were then obtainedafter initial positioning new sets of artificial teeth inside the silicone impression, pouring molten wax and fully seating a duplicate stone cast onthe mold. After bench cooling, wax-simulated dentures were removed from the silicone and invested in metal dental flasks as usual (Jon 5.5; Jon Produtos Odontológicos, São Paulo, SP, Brazil) with dental stone. Wax was removed and two coats of sodium alginate (Isolak; Classico Dental Products, São Paulo, SP, Brazil) were used as a mould separator. A denture poly(methylmethacrylate) basedresin (Lucitone 550; Dentsply International Inc., York, PA, USA) was prepared according to the manufacturer's instructions by mixing 21 g polymer powder to $10 \mathrm{ml}$ monomer liquid. The denture base resin was placed into the moulds and flasks, closed under pressure, and polymerized (Termotron, P100; Termotron Equipamentos, Piracicaba, SP, Brazil) at $73^{\circ} \mathrm{C}$ for 90 min followed by immersion in boiling waterfor 30 min at $100^{\circ} \mathrm{C}$. After polymerization, flasks were bench cooled for $30 \mathrm{~min}$ and placed in tap water for $15 \mathrm{~min}$. The dentures were carefully removed from the flasks, trimmed using metal burs (Maxi-Cut; Dentsply-Maillefer, Ballaigues, Switzerland) and fin ished using 360, 400, 600 and 1200-grit abrasive papers (Norton; Saint Gobain Abrasivos Ltda, Guarulhos, SP, Brazil). After finishing, the dentures were polished on a wet rag wheel with pumice slurry followed by tin oxide and individually stored in distilled water for the period needed to stabilize water uptake of denture materials. This pre-saturation was performed in order to minimize the effects of water absorption during irradiation on the infiltration of denture base materials by $C$. albicans. Before using in the experiments, the dentures were steam sterilized.

\subsection{Yeast Cell Suspensions and Microwave Irradiation}

The microorganism selected was an American Type Culture Collection (ATCC, Rockville, MD)strain of $C$. albicans (10231). The microorganism was cultured in 600 $\mathrm{ml}$ of Tryptic Soy Broth (TSB) at $37^{\circ} \mathrm{C}$ on a rotating shaker. Yeast cell culture was centrifuged, rinsed in water and resuspended to $10^{8}$ cells $\mathrm{ml}^{-1}$ in cold distilled water [26].

The sterile dentures were individually placed in sterile beakers containing $200 \mathrm{ml}$ of the yeast suspension, in order to completely cover the denture [27]. Each beaker was separately placed on a rotational plate in a conventional home microwave oven (Sensor Crisp 38, Double Emission System; Brastemp SA, Manaus, Amazonas, Brazil) and irradiated at $650 \mathrm{~W}$ for 1, 2, 3, 4 or $5 \mathrm{~min}$ (experimental suspensions - ESs) $[28,29]$. This procedure simulated the disinfection of a contaminated prosthesis so that the acrylic resin denture absorbed part of the microwave energy during irradiation [16]. After cooling, sterile distilled water was added to replace the amount of liquid lost by evaporation during irradiation. Control suspensions (CSs) were prepared identically to the ESs and placed in sterile beakers containing the sterile acrylic resin denture. These beakers were individually kept in the microwave oven for the same period of ESs, without irradiation.

Two ESs and two CSs from each microwave protocol were prepared and treated as described, before determination of yeast cell counts and leakage of proteins, electrolytes and DNA. All experiments were made in duplicates. Sample size was determined by power analysis.

\subsection{Yeast Cell Counts}

Yeast cell counts were made as previously described by Campanha et al. [21] Samples of suspensions were counted following uptake of methylene blue dye as indicative of yeast cell membrane damage [30]. In this assay, damaged and non-damaged yeast cell membranes were considered as indicative of live and dead yeast cells, respectively. For this purpose, samples of CSs and ESs were both serially diluted in $0.9 \% \mathrm{NaCl}$ solution from $10^{-1}$ to $10^{-6}$ cells $\mathrm{m}^{-1}$. Replicate samples of $0.5 \mathrm{ml}$ of each dilution were added to $55 \mu$ l of $0.05 \%$ methylene blue(w/v, prepared in sterile distilled water), mixed carefullyandleft for $5 \mathrm{~min}$ at room temperature [30]. Yeast cell concentrations (cells $\mathrm{ml}^{-1}$ ) were determined by opticalcount in samples of $10 \mu \mathrm{l}$ in a Neubauer chamber. $\log _{10}$-transformed numbers of damaged and non-damaged yeast cells of each sample were recorded. 
Replicate samples $(25 \mu \mathrm{l})$ of ESs and CSs were placed on Agar Sabouraud dextrose (ASD) plates at dilutions of $10^{-1}$ to $10^{-6}$, to determine total viable yeast cells. All plates were incubated at $37^{\circ} \mathrm{C}$ for $48 \mathrm{~h}$. After incubation, yeast colony counts of each plate were quantified using a dig ital colony counter (CP 600 Plus, Phoenix Ind Com Equipamentos Científicos Ltda, Araraquara, SP, Brazil). Colony-forming unit per milliliter $\left(\mathrm{CFU} \mathrm{ml}^{-1}\right)$ was determined and $\log _{10}$-transformed [31].

\subsection{Leakage of Proteins, Electrolytes and DNA}

The suspensions were submitted to analyses for determination of protein, electrolytes $\left(\mathrm{Ca}^{++}\right.$and $\left.\mathrm{K}^{+}\right)$and DNA releasedfrom the yeast cells, as previously described by Campanha et al. [21]. ESs or CSs were centrifuged at $1,500 \mathrm{~g}$ for $10 \mathrm{~min}$ and filtered with a $0.45 \mu \mathrm{m}$ acetate cellulose filter. Filtrates were freezedried (LyofilizerFreeZone 6 Liter Benchtop, Labconco Corporation, Kansas City, MU, USA), resuspended in $5 \mathrm{ml}$ of sterilized deionized water, frozen and stored until use.

Released protein content from ESs and CSs was quantified by two colorimetric methods: Bradford [12,32] and Pyrogallol red [33]. Microprote system (Doles Reagentes, Goiânia, GO, Brazil), based on the Bradford method, involves binding of Coomassie Brilliant Blue to the protein. This method measures the shift in the absorption spectrum of the dye that occurs when it binds to protein molecules: the absorbance peak shifts from 465 $\mathrm{nm}$ to $610 \mathrm{~nm}$. The system consisted of a stabilizer solution (Percloric Acid Solution $6.80 \mathrm{~mol} \mathrm{l}^{-1}$ ), Coomassie (Coomassie Brilliant Blue solution $1.2 \mathrm{mmol}$ ) and a standard solution (aqueous solution of human albumin $10 \mathrm{mg} \mathrm{dl}{ }^{-1}$ ). Absorbance was read at $610 \mathrm{~nm}$ (Spectrophotometer 482, Femto Ind. Com. de InstrumentosLtda) and the results were expressed by the following equation, where $A$ is the absorbance at $610 \mathrm{~nm}$.

$$
\left(A_{\text {test }}-A_{\text {stan dant }}\right) \times \frac{10}{A_{\text {stan dant }} \times A_{\text {blank }}}=m g d l^{-1} \text { protein }
$$

Sensiprote systems (LabtestDiagnóstica SA, Lagoa Santa, MG, Brazil) uses the Pyrogallol red-molybdate complex method. Binding of the dye (Pyrogallol redmolybdate) to protein causes a shift in the absorption maximum of the dye from $460 \mathrm{~nm}$ to $600 \mathrm{~nm}$. The system consists of a colour reagent (containing $\geq 60 \mu \mathrm{mol} 1^{-1}$ of Pyrogallol red; $\geq 40 \mu \mathrm{mol} \mathrm{l^{-1 }}$ of sodium molybdate; 1 mmoll ${ }^{-1}$ of sodium oxalate; $50 \mathrm{mmoll}^{-1}$ of buffer solution, $\mathrm{pH} \quad 2.5$; octylphenol poly-oxyethanol $0.1 \%$ and preservatives) and a standard reagent based on $0.05 \%$ of sodium azide. Absorbance was read at $600 \mathrm{~nm}$ (Spectrophotometer 482, Femto Ind. Com. de InstrumentosLtda) and the results were expressed by the following equation, where $A$ is the absorbance at $600 \mathrm{~nm}$.

$$
\frac{A_{\text {test }}}{A_{\text {stan dant }}} \times 50=m g d l^{-1} \text { protein }
$$

Amount of $\mathrm{Ca}^{++}$released from ESs and CSs was determined by a colorimetric system(Calcium Liquiform, Labtest Diagnóstica SA), based onthe Cresolftaleine Complex one method $[34,35]$. The reaction involves binding of $\mathrm{Ca}^{++}$to purple-coloured phthalein in alkaline medium. The system consisted of Reagent 1, containing buffer $920 \mathrm{mmol} \mathrm{l}^{-1}$, pH 12, sodium azide $19 \mathrm{mmol} \mathrm{l}^{-1}$; Reagent 2, containing o-cresolphthaleincomplexone 320 $\mu \mathrm{mol} \mathrm{l} \mathrm{l}^{-1}$, hydroxyquinoleine $13 \mathrm{mmol} \mathrm{l}^{-1}$ and hydrochloric acid $130 \mathrm{mmoll}^{-1}$; and a standard solution, containing calcium $10 \mathrm{mg} / \mathrm{dl}$ and formol $0.1 \%$. Absorbance was read at $570 \mathrm{~nm}$ (Technicon Ra-XT; Bayer Diagnostics Manufacturing Ltd, Swords Co, Dublin, Ireland) and the results were expressed by the following equation, where $A$ is the absorbance at $570 \mathrm{~nm}$.

$$
\frac{A_{\text {test }}}{A_{\text {standant }}} \times 10=m g d l^{-1} \mathrm{Ca}^{++}
$$

For all colorimetric systems described above, deionized water and specific reagents were used for the calibration of the spectrophotometer (blank). Standard curves of linearity supplied by manufacturers were used in order to calculate the concentrations of protein or calcium in the solutions. In order to compensate for increased concentrations in substances due to volume reduction (from $200 \mathrm{ml}$ to $5 \mathrm{ml}$ ) generated by lyophilization process, the obtained results were divided by 40 .

The determination of $\mathrm{K}^{+}$contents was carried out using a potassium ion selective electrode (Electrocyte Analyser AVL 9180, AVL Scientific Corporation, Roswell, GA, USA). In order to compensate for increased concentrations due to volume reduction (from 200 to $5 \mathrm{ml}$ ) generated by lyophilization process, the results obtained $\left(\mathrm{mmol}^{-1}\right)$ were divided by 40 .

DNA contents of the samples were determined by reading the absorbance of the filtrates (in replicates) against the appropriated blank (saline solution) at $260 \mathrm{~nm}$ (Spectrophotometer 482, Femto Ind. Com. de Instrumentos Ltda) $[8,12,30]$. The spectrophotometer was calibrated with deionized water. The results of two OD readings were transformed in DNA concentration, according to the following formula, where $A$ is the absorbance of the filtrates at $260 \mathrm{~nm}$ and d.f.was the dilution factor (1/40) [8].

$$
\text { DNA concentration }\left(\mu \mathrm{g} \mathrm{ml}^{-1}\right)=A_{260 \mathrm{~nm}} \times 50 \times d . f
$$

\subsection{Flow Cytometry Analysis}

Flow cytometry analysis of Candida cells was performed using propidium iodide. Yeast cell culture was centrifuged, rinsed in water and resuspended to $10^{6}$ cells $\mathrm{ml}^{-1}$ in sterile beakers containing $200 \mathrm{ml}$ in cold distilled water [26]. Each beaker was separately placed on a rotational plate in a conventional home microwave oven (Sensor Crisp 38, Double Emission System; Brastemp SA, Manaus, Amazonas, Brazil) and irradiated at $650 \mathrm{~W}$ for 1 , 2, 3, 4 or 5 min (experimental suspensions - ESs) [28,29]. Control suspensions (CSs) were prepared identically to the ESs. These beakers were individually kept in the microwave oven for the same period of ESs, without irradiation. Propidium iodide solution in $\operatorname{PBS}(5 \mu \mathrm{l})$, a marker that only penetrates cells with severe lesions of the membrane, was added to the cell suspensions in order to obtain a final concentration of $1 \mu \mathrm{g} / \mathrm{ml}$. The samples were then incubated at $35^{\circ} \mathrm{C}$ for $30 \mathrm{~min}$ in the dark. Unstained cells were always included as auto-fluorescence controls. 
Cell-associated fluorescence was measured using aFACSCalibur flow cytometer (Becton-Dickinson Biosciences).

\subsection{Statistical Analysis}

Original values obtained after cell counting (Neubauer chamber) and after colony countings (ufc/mL) were log transformed before group comparisons. It was calculated the linear regression coefficient between two variables. The linear equation was $\mathrm{y}=\mathbf{a}+\mathbf{b}^{*}$ Time, where $\mathbf{a}$ and $\mathbf{b}$ were the intercept and regression coefficient, respectively, of the prediction equations of released substances or cell counts (y). Average values of the duplicates were submitted to statistical analysis. Pairwise Student's $t$-test was used to evaluate if $\mathbf{a}$ or $\mathbf{b}$ were different from zero (5\% of significance).In theflow cytometry analysis, expression of mean fluorescence intensity of propidium iodide staining was determined.

\section{Results}

Results from optical counts using methylene blue dye uptakeas indicative of membrane damaged or nondamaged cells, are illustrated in Figure 1 and 2, respectively. For ESs, damaged cell counts remained similar for all irradiation times tested, exceptfor 1 minperiod (Figure 1). When non-damagecells were considered (Figure 2) all record counts from CS were significant different from zero $(P<0.001)$. Non-damaged cell counts also showed similar behavior between ES and $\mathrm{CS}$ at 1 min of irradiation, but after 3 min cell counts they were decreased to zero (Figure 2).

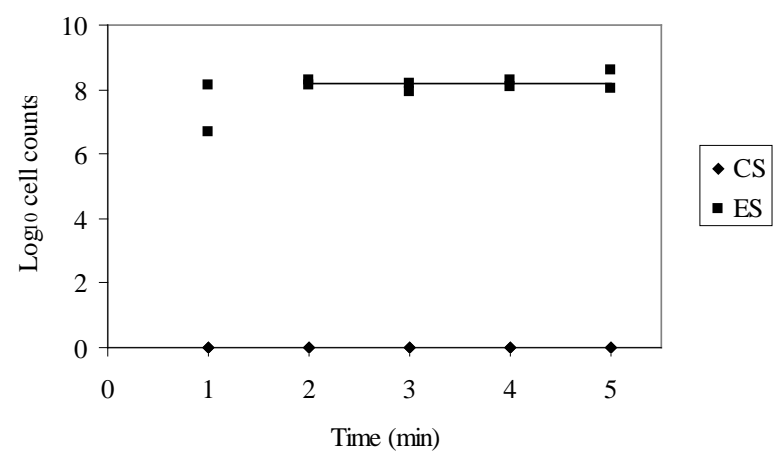

Figure 1. $\log _{10}$-transformed values of damaged yeast cells of CSs and ESs (Mean of ESs group is represented by the horizontal bar)

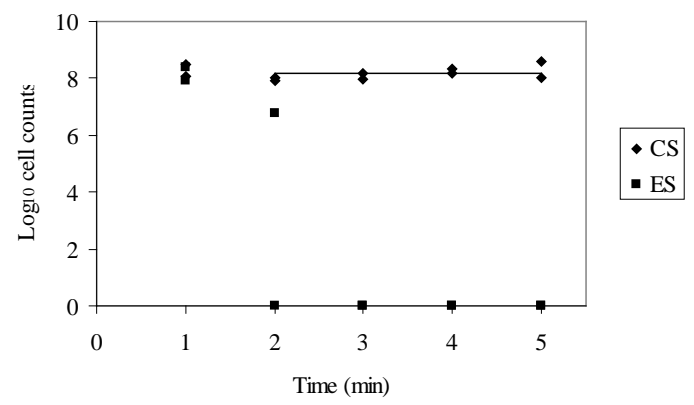

Figure 2. $\log _{10}$-transformed values (ufc $\mathrm{ml}^{-1}$ ) of non-damaged yeast cells of CSs and ESs (mean values of CSs group is represented by the horizontal bar)

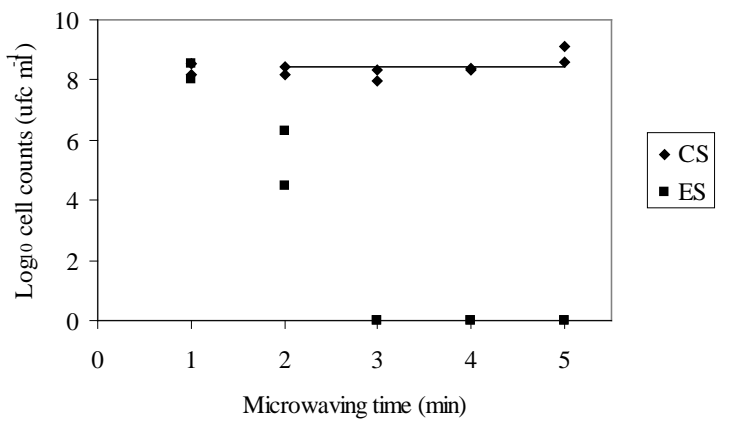

Figure 3. $\log _{10}$-transformed values of ufc $\mathrm{ml}^{-1}$ yeast cells from CSs and ESs (mean values of CSs group is represented by the horizont al bar)

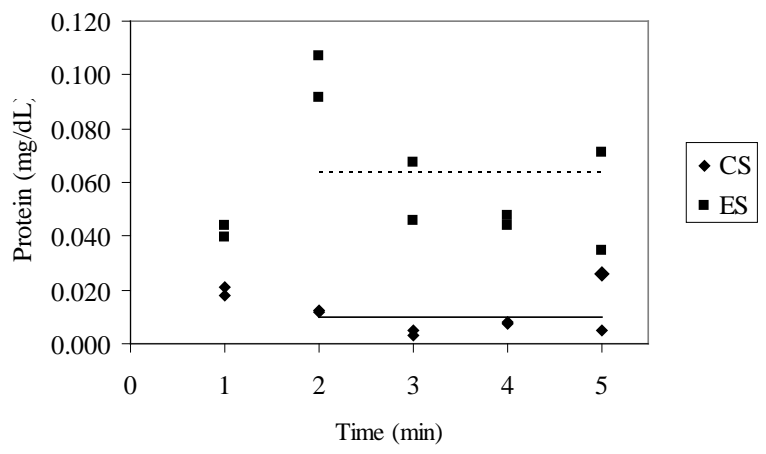

Figure 4. Mean values of protein concentration, as determined by Microprote system (CSs group is represented by the horizontal bar and dashed line represents ESs group)

Figure 3 shows log (ufc ml-1) values obtained from CSs and ESs. Decrease of C. albicansviability was dependent on the irradiation time tested. A significant reduction was observed after 2 min of irradiation, and the absence of colony growth (complete killing of the microorganis $\mathrm{m}$ ) was achieved with irradiation during $3 \mathrm{~min}$ or more. Substantial microbial growth was observed in all plates of CS groups.

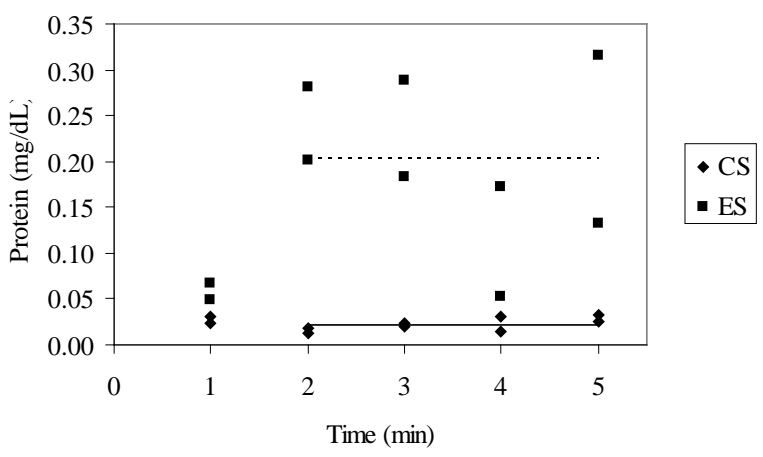

Figure 5. Mean values of protein concentration, as determined by Sensiprote system (CSs group is represented by the horizontal bar and dashed line represents ESs group)

Figure 4 and Figure 5 show mean values of protein concentration obtained from CS and ES groups, as determined by Microprote and Sensiprote systems, respectively. The values of control suspension for protein release were very close to the mean, especially for $2 \mathrm{~min}$ to $5 \mathrm{~min}$. For both systems, protein contents released from 
ESs were higher than the control when irradiation times of 2 min or higher were considered. There was no evidence of correlation between protein and time using Microprote system $(P>0.05)$ but there was evidence with Sensiproteat some extent $(P=0.041)$.

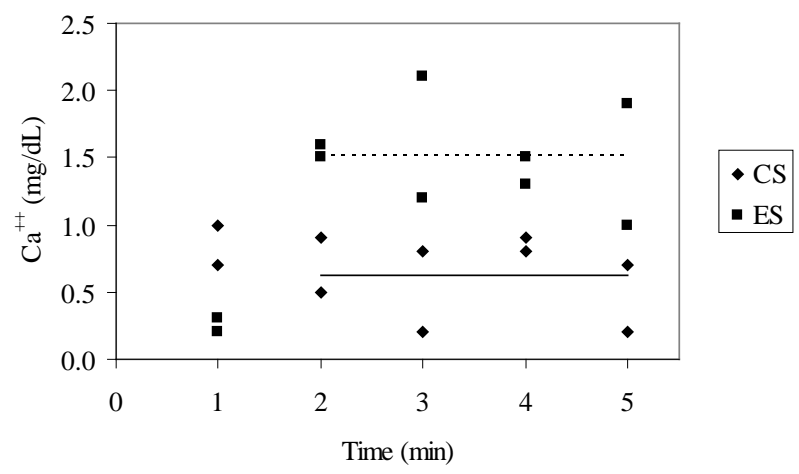

Figure 6. Mean values of $\mathrm{Ca}^{++}$concentration (mean of CSs group is represented by the horizontal bar and dashed line represents ESs group)

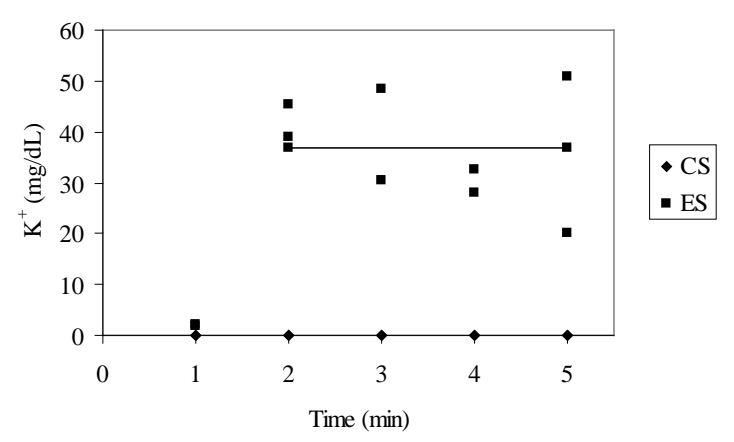

Figure 7. Mean values of $\mathrm{K}^{+}$concentration (mean of CSs group is represented by the horizontal bar and dashed line represents ESs group)

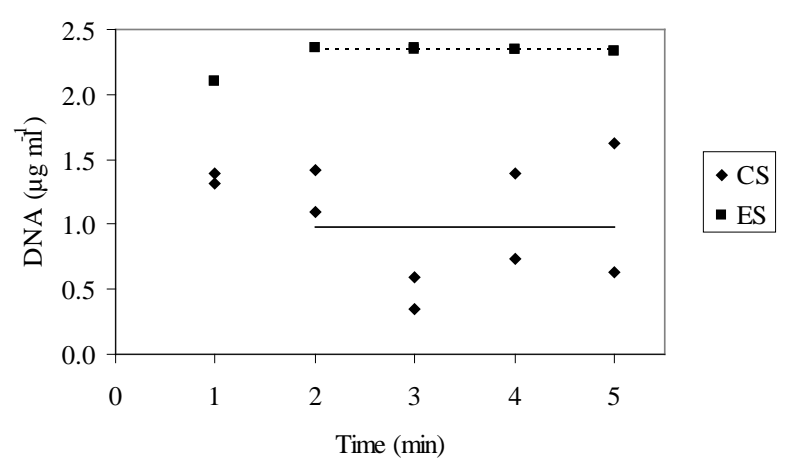

Figure 8. Mean values of DNA concentration (mean of CSs group is represented by the horizontal bar and dashed line represents ESs group)

Figure 6, Figure 7 and Figure 8 show mean values of $\mathrm{Ca}^{++}, \mathrm{K}^{+}$and DNA concentration obtained from CS and ES groups, respectively. The results suggested that, independent of the time, ESs released more substances than CSs. The results of $\mathrm{Ca}^{++}$release showed similar values of CS and ES only when 1 min time was evaluated. In general, the mean values of ES were 2.5 times higher than the mean values of CS. No signal of $\mathrm{K}^{+}$release was found in CS samples, while ES showed high levels of this electrolyte after irradiation times starting at $2 \mathrm{~min}$. Higher levels of DNA were detected in the ES, as compared to CS, regardless of the irradiation time evaluated. After 2 min of irradiation, there was no further increase in the leakage of DNA from ES groups, suggesting that the release of this nucleic acid was not time-dependent.

The Figure 9 shows that similar results to the described above were observed in the flow cytometry analysis. Similar values of CS and ES were found only when $1 \mathrm{~min}$ time was evaluated.

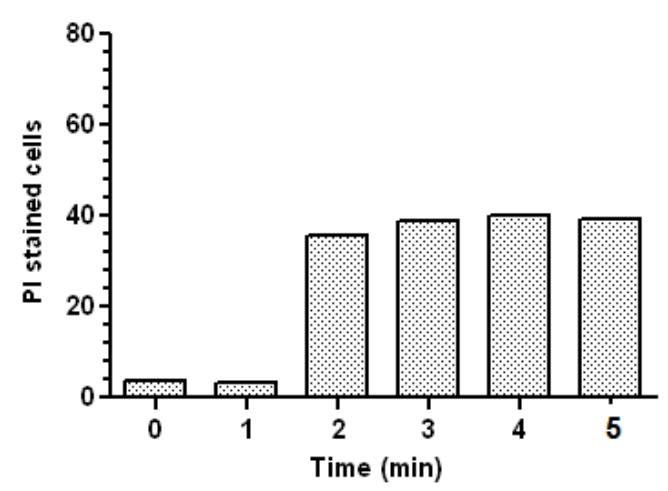

Figure 9. Kinetic study showing propidium iodide stained cells microwaved during $0,1,2,3,4$ and 5 minutes

\section{Discussion}

When selecting a disinfection procedure, its effect on the physical and mechanical properties of the denture materials shouldbe carefully considered [36,37]. Previous clinical studies showed that microwave disinfection at 650 $\mathrm{W}$ for $3 \mathrm{~min}$ did not cause detrimental effects on the linear dimensional stability of complete dentures [38]. Thus, the present study was conducted to gain additional understanding on the cellular effects of different exposure times of microwave irradiation on Candida albicans cells.

Growth potential is one of the most used parameters for evaluation of destruction or inactivation of microorganis ms. In addition, liberation of molecules and intracelular ions such as electrolytes, DNA, RNA, and proteins can help to evaluate cell lysis [39]. Hence, the mechanisms of inactivation of microoganisms by microwavescan be studied at structural and microbial molecular levels by counting the viable cells and release of intracellu lar substances, as parameters of cell lysis.

Whole cells were not found in the experimental suspension for times greater than $3 \mathrm{~min}$, aftercell count in aNeubauer chamber(Figure 1 and Figure 2). Cells in this suspension lost their refringence characteristic, and became bluish, while still preserved their elipsoidal morphology. According to this methodology, the distinction between intact and non-intactcells is made on the basis of intake of blue methylene dye which is an indirect manner to evaluate the permeability of the membrane and cell walls. Therefore, the obtained results indicate that there was a change of the integrity or permeability of the membrane of cells irradiated for more than $3 \mathrm{~min}$. The results of this study agreed with Mimaet al. [36], who observed changes in cell morphology after microwave irradiation for 3 min under scanning electron microscopy(SEM) analysis. 
Regarding the values of CFU ml-1, it was observed that the number was reduced to zero after 3 min (Figure 3 ). The results of this study are in accordance with other studies. Sanitá et al. [5] proved the hypothesis that simulated complete dentures inoculated with five species of Candida, isolated from $\mathrm{HIV}$-infected patients and ATCC strains, could be sterilized by microwave irradiation. The results demonstrated that all dentures contaminated with Candida species, regardless of its source (clinical or ATCC), showed uniform sterilization after 3 min of micro wave irradiation at $650 \mathrm{~W}$.In the study of Mima et al. [36], SEM analysis indicated that microwave irradiation for 3 min produced changes in cell morphology for sterilized specimens. However, 1 min and 2 min exposition resulted in disinfection of the specimens. In addition, Dovigo et al. [1] found that microwave irradiation for $3 \mathrm{~min}$ at $650 \mathrm{~W}$ produced sterilization of complete dentures contaminated with $S$. aureus and Pseudomonas aeruginosa.

The release of proteins and ions, suggestive of cell me mb rane damage occurred after 2 to 5 min of irradiation at $650 \mathrm{~W}$ (Figure 4, Figure 5, Figure 6 and Figure 7). It would be assumed that the antimicrobial mechanism action of microwaves changed the permeability of cell membrane, and subsequent permeabilization of the membrane caused leakage of intracellular constituents, leading to cell death. Protein molecules are generally very large to pass through undamaged cell membranes [21]. So, loss of protein to the external medium means that the cell was not able to undertake most, if not all, of its essential functions. $\mathrm{Ca}^{++}, \mathrm{Na}^{++}$and $\mathrm{K}^{+}$ions play specific cell roles and their concentrations in the extracellular environment are maintained through in tramembranous active transport mechanisms. Therefore, ions contents obtained from irradiated cells suggest that the ions were released by vacuole to the cytoplasm, and then to extracellular reg ions after irradiation.

There was a higher concentration of released nucleic acids (Figure 8)for the same experimental groups (2, 3, 4 and $5 \mathrm{~min}$ of irradiation at $650 \mathrm{~W}$ ), suggesting changes in the cell nuclei. Because nucleic acids(DNA and RNA) are found inside organelles involved by phospholipidic membranes, these molecules can only be released by the microorganis $m$ to the extracellular after changing of these membranes [40]. Since DNA is responsible for genetic propagation, the loss of this molecule may be accounted for the lack of growth of the cells from the ESs [40]. The probable explanation is that microwave irradiation accelerates chemical reactions, causing numerous intermolecular collisions making the rotational energy to be converted in thermal energy [9,41].The resulting increase of temperature could cause denaturation of proteins and DNA. These results are in accordance with Lore et al. [42] who observed that, although the microorganism (influenza virus)had been completely inactivated by microwave irradiation, the PCR method was able to detect viral genomic material in the samples. Further investigation is required to determine whether the increase of leakage of electrolytes, proteins and DNA was the cause or the result of microwave-induced cell death. In addition, microwave irradiation has been demonstrated not only to dramatically accelerate a number of organic reactions, but also the activity of various enzymes can be significantly increased when exposed to microwaves
$[41,43]$. However, after 3 or $4 \mathrm{~min}$ of irradiation, the temperature rose to above $50^{\circ} \mathrm{C}$, imply that cell inactivation could be a consequence of overheating [41].

Data obtained under the conditions of this study also showed that, microwave irradiation for $1 \mathrm{~min}$ at $650 \mathrm{~W}$ resulted in survival of the $C$. albicans cells. There were no statistical differences for all parameters used for identification and observation of microorganisms after irradiation for $1 \mathrm{~min}$ at $650 \mathrm{~W}$. From this period of irradiation, it was possible to suppose that microwaves did not cause thermal or nonthermal effects on the evaluated microorganis ms.

It is known that microwave irradiation is akind of radio frequency energy that excites water molecules, generating heat [42], and it has been applied to inactivateor reduce several species of microorganisms [1,12,20,25]. The explanation about microbial killing with microwave irradiation, however, is not yet completely understood. Two potential explanations have been considered: the thermal effect and non-thermal effect [44]. Regarding the thermal effect, it is believed that microorganisms absorb microwave energy, resulting in thermal death [45]. In addition, Parker [46] found that the effect of microwave irradiation is strongly correlated with water activity. Destruction of microorganisms by the non-thermal effect could be explained by absorption of micro wave irradiation by certain biochemical molecules, such as proteins and nucleic acids. So, the interaction between electromagnetic field produced by the microwaves and the cell molecules would lead to cell destruction [47]. It is also suggested that one of the antifungal effect with microwaves is due to the fact that the temperature rise in the microorganis $m$ is greater than that of the surrounding medium. In addition, the microorganisms themselves have thermal properties, which are directly involved with microbial destruction [16]. The microorganisms can absorb microwave thermal heat at a much greater rate than the surrounding liquid medium [16]. In addition, it has been suggested that micro waves are not sufficiently strongto directly change chemical bonds and their effects have been attributed to other mechanisms such as dielectric relaxation, ionic conductivity and biopolymer alteration [7]. However, microwave heating is energy conversion and not heating as in a conventional oven, sothe microwave absorbent material exposed to a microwave field converts this energy into heat within itself [47]. In this context, Senna et al. [48] reported that microwave irradiation reaches the microorganis m killing temperature more effectively than conventional heating process, which needs to heat the entire environ ment.

In this study, propidium iodide, a nucleic acid-binding fluorescent probe, was used to evaluate the effect of microwave on cell membranes. Cells with membrane lesions leading to inherent loss of viability internalize propidium iodide, resulting in an increase in red fluorescence $[49,50]$. The Figure 9 shows the propidium iodide penetration in cells treated with several times in microwave. The results showed a change in the integrity or permeability of the membrane of cells irradiated after 2 min. After the short period of 1 minute in microwave, few cells were propidium iodide positive, i.e. almost $100 \%$ cells were viable, with intact membranes.

The methodology of this study did not testthe adhesion of $C$. albicans to the dentures surfaces. Biofilms formed 
by C. albicans, associated or not with other species of microorganis ms, are known to be more resistant to the action of antifungal treatments [51]. A methodology including the development of biofilms should be considered for future investigations. The efficacy of a lower power setting (450 W) was confirmed earlier [48], and has shown to be effective for disinfecting mature C.albicans biofilms, at a supposedly safer temperature for denture base acrylic resins. Therefore, the effect of other power densities of microwave irradiation on the inactivation and cell membrane integrity damage of $C$. albicans should be evaluated.

\section{Conclusions}

The findings of this study demonstrated that micro wave irradiation at $650 \mathrm{~W}$ for 2 min promoted cell death of $C$. albicans through leakage of proteins, electrolytes and DNA, detectable by different assays. In addition, yeast cell suspensions were $100 \%$ inactivated after irradiation for 3 min, suggesting sterilization of the samples. The results provided important insight towards a better understanding of the mechanis ms involved in cell death of C. albicans after micro wave irradiation.

\section{Statement of Competing Interests}

The authors have no competing interests'.

\section{References}

[1] Dovigo LN, Pavarina AC, Ribeiro DG, de Oliveira JA, Vergani $\mathrm{CE}$, Machado AL. Microwave disinfection of complete dentures contaminated in vitro with selected bacteria. J Prosthodont 2009; 18: 611-617.

[2] Ribeiro DG, Pavarina AC, Dovigo LN, de Oliveira Mima EG, Machado AL, Bagnato VS et al. Photodynamic inactivation of microorganisms present on complete dentures. A clinical investigation. Lasers Med Sci 2012; 27: 161-168.

[3] Gendreau L, Loewy ZG. Epidemiology and etiology of denture stomat itis.J Prosthodont 2011; 20: 251-260.

[4] Samaranayake LP, MacFarlane TW. 1990. Oral Candidosis. Wright-Butterworth, London, UK.

[5] Sanitá PV, Vergani CE, Giampaolo ET, Pavarina AC, Machado AL. Growth of Candida species on complete dentures: effect of microwave disinfection. Mycoses 2009; 52: 154-160.

[6] Dardalhon M, Averbeck D, Berteaud AJ. Studies on possible genetic effects of microwaves in procaryotic and eukaryotic cells. Rad Environ Biophys 1981; 20: 37-51.

[7] Najdovski L, Dragas AZ, Kotnik V. The killing activity of microwaves on some non-sporogenic and sporogenic medically import ant bacterial strains.J Hosp Infect 1991; 19: 239-247.

[8] Ponne CT, Bartels PV. Interaction of electromagnetic energy with biological material - relation to food processing.RadiatPhysChem 1995; 45: 591-607.

[9] Atmaca S, Akdag Z, Dasdag S, Celik S. Effect of microwaves on survival of some bacterial strains. ActaMicrobiolImmunol Hun 1996; 43: 371-378.

[10] Pakhomov AG, Akyel Y, Pakhomova ON, Stuck BE, Murphy MR. Current state and implications of research on biological effects of millimeter waves: a review of the literature. Bioelectromagnetics 1998; 9: 393-413.

[11] Watanabe N, Kamei S, Ohkubo A, Yamanaka M, Ohsawa S, Makino K, Tokuda K. Urinary protein as measured with a pyrogallol red-molybdate complex, manually and in a Hitachi 726 automated analyzer. ClinChem 1986; 32: 1551-1554.
[12] Woo I, Rhee I, Park H. Differential damage in bacterial cells by microwave radiation on the basis of cell wall structure. Appl Environ Microbiol 2000; 66: 2243-2247.

[13] Hong SM, Park JK, Lee YO. Mechanisms of microwave irradiation involved in the destruction of fecal coliforms from biosolids. Water Research 2004; 38: 1615-1625.

[14] Carroll DE, Lopez A. Lethality of radio-frequency energy upon microorganisms in liquid, buffered, and alcoholic food systems. $J$ Food Sci 1969; 34: 320-324.

[15] Fitzpatrick JA, Kwao-Paul J, Massey J. Sterilization of bacteria by means of microwave heating. J ClinEng 1978; 3: 44-47.

[16] Fujikawa H, Ushioda H, Kudo Y. Kinetics of Escherichia coli destruction by microwave irradiation. Appl Environ Microbiol 1992; 58: 920-924.

[17] Yeo CB, Watson IA, Stewart-Tull DE, Koh VH. Heat transfer analysis of Staphylococcus aureus on stainless steel with microwave radiation.J ApplMicrobiol 1999; 87: 396-401.

[18] Culkin KA, Fung DYC. Destruction of Escherichia coli and Salmonella typhimurium in microwave-cooked soups.J Milk Food Technol 1975; 38: 8-15

[19] Dreyfuss MS, Chipley JR. Comparison of effects of sublethal microwave radiation and conventional heating on the metabolic activity of Staphylococcus aureus. Appl Environ Microbiol 1980; 39: 13-16.

[20] Rosaspina S, Salvatorelli G, Anzanel D, Bovolenta R. Effect of microwave radiation on Candida albicans. Microbios 1994; 78 : 55-59.

[21] Neppelenbroek KH, Pavarina AC, PalomariSpolidorio DM, SgavioliMassucato EM, Spolidorio LC, Vergani CE. Effectiveness of microwave disinfection of complete dentures on the treatment of Candida-related denture stomatitis.J Oral Rehabil 2008; 35 836-46.

[22] Campanha NH, Pavarina AC, Brunetti IL, Vergani CE, Machado AL, Spolidorio DM..Candida albicans inactivation and cell membrane integrity damage by microwave irradiation. Mycoses 2007; 50: 140-147.

[23] Campanha NH, Pavarina AC, Vergani CE, Machado AL. Effect of microwave sterilization and water storage on the Vickers hardness of acrylic resin denture teeth. J ProsthetDent 2005; 93: 483-487.

[24] Pavarina AC, Neppelenbroek KH, Guinesi AS, Vergani CE, Machado AL, Giampaolo ET. Effect of microwave disinfection on the flexural strength of hard chairside reline resins. J Dent Res 2005; 33: 741-748.

[25] Webb BC, Thomas CJ, Whittle T. A 2-year study of Candidaassociated denture stomatitis treatment in aged caresubjects.Gerodontology 2005; 22: 168-176.

[26] Sanita PV, Machado AL, Pavarina AC, Massucato EM, Colombo AL, Vergani CE. Microwave denture disinfection versus nystat in in treating patients with well-controlled type 2 diabetes and denture stomatitis: a randomized clinical trial. Int J Prosthodont 2012; 25: 232-244.

[27] Boriollo MFG, Rosa EAR, Bernardo WLC, Spolidorio DMP, Gonçalves RB, Hofling JF.Multilocus enzyme electrophoresis typing of Candida albicans populations isolated from healthy children according to socioeconomic background. Rev Bras Epidemiol 2005; 8: 51-66.

[28] Harrison Z, Johnson A, Douglas CW. An in vitro study into the effect of a limited range of denture cleaners on surface roughness and removal of Candida albicans from conventional heat-cured acrylic resin denture base material.J Oral Rehabil2004; 31: 460467.

[29] Neppelenbroek KH, Pavarina AC, Spolidorio DMP, Vergani CE, Mima EG, Machado AL. Effectiveness of microwave sterilization on three hard chairside reline resins. Int J Prosthodont 2003; 16: 616-620.

[30] Silva MM, Vergani CE, Giampaolo ET, Neppelenbroek KH, Spolidorio DM, Machado AL. Effectiveness of microwave irradiation on the disinfection of complete dentures. Int $J$ Prosthodont 2006; 19: 288-293.

[31] Hammer KA, Carson CF, Riley TV. Antifungal effects of Melaleucaalt ernifolia (tea tree) oil and its components on Candida albicans, Candida glabrata and Saccharomyces cerevisiae.J Antimicrob Chemother 2004; 53: 1081-1085.

[32] Chan EC, Iugovaz I, Siboo R, Bilyk M, Barolet R, Amsel R, Wooley C, Klitorinos A. Comparison of two popular methods for removal and killing of bacteria from dentures. J Can Dent Assoc 1991; 57: 937-939. 
[33] Bradford MM. A rapid and sensitive method for the quant itation of microgram quantities of protein utilizing the principle of protein-dye binding. Anal Biochem 1976; 72: 248-254.

[34] Kang HP, Scott MG, Joe BN, Narra V, Heiken J, Parvin CA. Model for predicting the impact of gadolinium on plasma calcium measured by the o-cresolphthalein method. Clinical Chemistry 2004; 50: 741-746.

[35] Wible JH Jr, Hynes MR. Measurement of serum calcium concentration after administration of gadoversetamide in dogs. Radiology 2004; 233: 158-164.

[36] Smith DC. The cleansing of dentures. Dent Pract Dent Rec 1966; 17: 39-43.

[37] Mima EG, Pavarina AC, Neppelenbroek KH, Vergani CE, Spolidorio DM, Machado AL. Effect of different exposure times on microwave irradiation on the disinfection of a hard chairside reline resin. J Prosthodont2008; 17: 312-317.

[38] Basso MF, Giampaolo ET, Vergani CE, Machado AL, Pavarina AC, Compagnoni MA. Influence of microwave disinfection on the linear dimensional stability of complete dentures: a clinical study. Int J Prosthodont 2010; 23: 318-320.

[39] Khalil H, Villota R. Comparative study on injury and recovery of st aphylococcus aureus using microwave and conventional heat ing. J Food Prot 1988; 51: 181-186.

[40] Maniatis T, Sambrook J, Fritsch EF. 1989. Molecular cloning: a laboratory manual. Cold Spring Harbor: Cold Spring Harbor Laboratory.

[41] Bezbradica D, Mijin D, Mihailovic M, Knezevic-Jugovic Z. Microwave-assisted immobilization of lipase from Candida rugosa on Eupergit supports. J Chem Technol Biotechnol 2009; 84: 16421648.

[42] Lore MB, Heimbuch BK, Brown TL, Wander JD, Hinrichs SH. Effectiveness of three decontamination treatments against influenza virus applied to filtering face piece respirators. Ann OccupHyg 2012; 56: 92-101.

[43] Makawana JA, Mungra DC, Patel MP, Patel RG. Microwave assisted synthesis and antimicrobial evaluation of new fused pyran derivatives bearing 2-morpholinoquinoline nucleus. Bioorg Med Chem Lett 2011; 21: 6166-6169.

[44] Brondani M, Samim F, Feng H. A conventional microwave oven for denture cleaning: a critical review. Gerodontology 2012; 29(2): e6-15.

[45] Corelli JC, Gutmann RJ, Kohazi S, Levy J. Effects of 2.6-4.0 GHz microwave radiation on E-coli B. J Microw Power 1977; 12: 141144.

[46] Parker LN. Thyroid suppression and adrenomedullary activation by low-intensity microwave radiation. Am J Physiol 1973; 224:1388-1390.

[47] Hamouda IM, Ahmed SA. Effect of microwave disinfection on mechanical properties of denture base acrylic resin.J MechBehav Biomed Mater 2010; 3: 480-487.

[48] Senna PM, Da Silva WJ, Del BelCury AA. Denture disinfection by microwave energy: influence of Candida albicans biofilm. Gerodontology2012; 29(2): e186-191.

[49] Pina-Vaz C, Sansonetty F, Rodrigues AG, et al. Cytometric approach for rapid evaluation of susceptibility of Candida strains to antifungals. ClinMicrobiol Infect 2001; 7: 609-18.

[50] Ahmad A, Khan A, Kumar P, Bhatt RP, Manzoor N.Antifungal activity of Coriarianepalensis essential oil by disrupting ergosterol biosynthesis and membrane integrity against Candida. Yeast. 2011; 28(8):611-7.

[51] Hawser SP, Douglas LJ. Resistance of Candida albicans biofilms to antifungal agents in vitro. Antimicrob Agents Chemother1995; 39: 2128-2131. 